\title{
Manoeuvring SME beach resorts in choppy environment: entrepreneurs' perspective
}

\begin{abstract}
This study seeks to understand how entrepreneurs of SME beach resorts mitigate challenges in their efforts to survive and simultaneously expand their businesses. SMEs in tourism related industry including beach resorts cater towards accommodating increased number of tourist arrivals. Malaysia targets to bring in 36 million tourists, with RM168 billion tourism receipts by the year 2020. The sun, sea and sand are naturally the magnets of tropical islands of Malaysia. The authors employed in-depth interview technique on two resorts located on Perhentian Kecil Island, offshore Terengganu, Malaysia. Observation of the premises complements data collected from interviews. Findings suggest that the resorts employed various strategies to manage their operations. Cost saving methods like employing family members, constructing additional resort features during monsoon period and smart business arrangement with resorts suppliers contributed towards resorts expansion. The study outcome would amongst others benefit policymakers in nurturing the SME sector, further facilitating Malaysia towards a developed nation. This study also contributes to the performance management literature particularly on island beach resorts
\end{abstract}

Keyword: Beach resort; Entrepreneurship; Performance management; Small and medium enterprises; SMEs; Tourism 